\title{
Geochemical modelling of the tonalitic and trondhjemitic granulites from the Itabuna-Salvador-Curaçá Block, Bahia, Brazil
}

\author{
Ivana Conceição de Araújo Pinho a, Johildo Salomão Figueiredo Barbosa a , \\ Angela Beatriz de Menezes Leal ${ }^{\mathrm{a}, *}$, Hervé Martin $^{\mathrm{b}}$, Jean-Jacques Peucat ${ }^{c}$ \\ ${ }^{a}$ UFBA, Universidade Federal da Bahia, Instituto de Geociências, CPGG, Centro de Pesquisa em Geofísica e Geologia, Rua Barão de Geremoabo, s/n, Federação, \\ 40170-209 Salvador, Bahia, Brazil \\ ${ }^{\mathrm{b}}$ Laboratoire Magmas et Volcans, Département de Géologie, OPGC, Université Blaise Pascal, CNRS, IRD, 5 rue Kessler, 63038 Clermont-Ferrand, France \\ ${ }^{\mathrm{c}}$ Géosciences Rennes, UMR CNRS 6118, Université de Rennes-1, 35042 Rennes Cedex, France
}

\section{A R T I C L E I N F O}

\section{Article history:}

Received 18 September 2009

Accepted 17 November 2010

\section{Keywords:}

High temperature metamorphism

Geochemical modelling

Paleoproterozoic granulites

São Francisco craton

Bahia, Brazil

\begin{abstract}
A B S T R A C T
The studied tonalitic and trondhjemitic granulites are located in the SSE granulitic domain of the São Francisco craton, Bahia, Brazil, where they represent most of the southern part of the Archean and Paleoproterozoic Itabuna-Salvador-Curaçá Block (ISCB). Chemically, the tonalitic and trondhjemitic granulites belong to a low-K calc-alkaline suite; their REE patterns are steep with strong LREE/HREE fractionation and no significant Eu anomaly. Garnet-bearing mafic granulites that occur as enclaves in the tonalitic and trondhjemitic granulites were derived from basalts and/or gabbros of tholeiitic affinity. Geochemical modelling showed that the tonalitic and trondhjemitic granulites were produced by moderate fractional crystallization of an assemblage of hornblende and plagioclase, with subordinate amounts of magnetite, apatite, allanite and zircon. The garnet-bearing mafic granulites would be the source of the magmas that generated these rocks. Partial melting left a residue made up of plagioclase, garnet, orthopyroxene and hornblende.
\end{abstract}

(c) 2010 Elsevier Ltd. All rights reserved.

\section{Introduction}

The Archean-Paleoproterozoic boundary marks changes in petrogenetic mechanisms at this time (Martin, 1986; Barbosa, 1990; Barbosa and Sabaté, 2002, 2004). At about 2.5 Ga komatiites almost stopped to be produced and also the tonalite, trondhjemite and granodiorite (TTG) association became scarcer. During the Archean, continental crust had TTG composition, and was supposed to be generated by melting of hydrated basalt, probably in a subduction environment (Martin, 1986). After $2.5 \mathrm{Ga}$ its growth was due to additions of the basalt, andesite, dacite and rhyolite (BADR) suite, generated by hydrous mantle peridotite melting in a subduction environment. This major petrologic change is classically interpreted as reflecting the progressive cooling of the Earth (Martin and Moyen, 2002). If it is possible to demonstrate a progressive change in TTG composition throughout

\footnotetext{
* Corresponding author. Tel.: +55 7132038606 .

E-mail addresses: ivanapinho@yahoo.com.br (I. Conceição de Araújo Pinho), johildo@cpgg.ufba.br (J.S. Figueiredo Barbosa), angelab@ufba.br (A. Beatriz de Menezes Leal), martin@opgc.univ-bpclermont.fr (H. Martin), peucat@univ-rennes1.fr (J.-J. Peucat).
}

the Archean at the world scale, maybe the transition was not abrupt at ca. $2.5 \mathrm{Ga}$. On the contrary, it was progressive since some TTG are found in Paleoproterozoic terrains. In addition, sanukitoids, which have chemical composition intermediate between TTG and BADR, were emplaced until the end of the Archean to the Paleoproterozoic, but now also includes younger rocks (Stern, 1989; Stern and Hanson, 1991; Smithies and Champion, 1999; De Souza et al., 2007; Lobach-Zhuchenko et al., 2008).

Tonalite and trondhjemites are abundant in the Itabuna-Salvador-Curaçá Block (ISCB), which is Paleoproterozoic in age and formed over a period of 200-300 Ma when the Itabuna-SalvadorCuraçá Block was squeezed between the Archean Gavião, Jequié and Serrinha blocks. This led to the formation of an important mountain range which is now completely eroded in the centre of the block where the high-grade metamorphic rocks of its roots are now exposed. This forms one of the world's most important granulite provinces (Barbosa, 1986).

The aim of this article is to present new data on the geology, petrography and rock geochemistry, as well as the results of geochemical modelling of the genesis of the tonalitic and trondhjemitic granulites and of the garnet-bearing basic granulites which are found in the southern part of the ISCB (Pinho, 2005). 


\section{Geological setting}

The São Francisco Craton which stabilized at the end of the Paleoproterozoic orogeny, before Espinhaço rifting, is located in the central-eastern part of South America. It is surrounded by the Araçuaí, Brasília, Rio Preto, Riacho do Pontal and Sergipana fold belts. In the stable part of the craton, Mesoproterozoic siliciclastic and Neoproterozoic carbonate sediments cover an Archean-Paleoproterozoic basement (Alkmim et al., 1993; Fig. 1). In this basement, Barbosa and Sabaté (2002) identified four distinct crustal segments, the Gavião (GB), Jequié (JB), Serrinha (SB) and Itabuna-SalvadorCuraçá (ISCB) blocks (Fig. 1).

The Gavião Block (GB) (Fig. 1) is made up of various orthogneisses including TTG suites with ages ranging from 3.5 to $2.7 \mathrm{Ga}$. They were metamorphosed and partially recycled, with migmatites and granites dated at ca. 2.6-2.5 Ga (Marinho, 1991; Martin et al., 1991; Santos Pinto, 1996; Bastos Leal et al., 2003; Peucat et al., 2003). Disrupted supracrustal belts are considered to be Archean. They generally consist of mafic to ultramafic flows overlain by felsic lavas with pyroclastic intercalations and siliciclastic sediments (Marinho, 1991; Cunha and Fróes, 1994; Mascarenhas and Silva, 1994).

The Jequié Block (JB) (Fig. 1) crops out between the Gavião Block and the Itabuna-Salvador-Curaçá Block. It consists of two main rock units. The older unit, dated at 3.0 Ga by Wilson (1987), is made up of heterogeneous felsic orthogranulites with subordinate mafic facies associated with kinzigites, iron formations, orthopyroxenebearing garnet quartzites and graphitites. The second unit is younger, with ages ranging from 2.7 to $2.6 \mathrm{Ga}$, and contains enderbitic, charno-enderbitic and charnockitic granulites (Alibert and Barbosa, 1992; Barbosa et al., 2004).

The Serrinha Block (SB) (Fig. 1) crops out at the northeastern extremity of the São Francisco Craton. It is composed of tonalite, granodiorite orthogneiss and amphibolites. In some places partial melting took place, and the migmatites produced ages ranging from 3.1 to $2.8 \mathrm{Ga}$ (Oliveira et al., 1999, 2000; Melo et al., 2000; Rios et al., 2005). The 2.0-2.2 Ga (Silva, 1996) Rio Itapicuru and Capim greenstone belts cover this basement, and were intruded by a wide variety of granites (Alves da Silva, 1994) with ages between 2.25 and 2.07 Ga (Rios et al., 2005).

The Itabuna-Salvador-Curaçá Block (ISCB) (Fig. 1) is located between these three blocks (Barbosa and Sabaté, 2002, 2004). The northern part is composed of TTG with imbrications of supracrustal rocks which are cut by products of anatectic melts, including granites. The southern part of the ISCB contains at least three major groups of granulites including: (1) mafic granulites associated with (3); (2) granulites derived from sedimentary rocks; (3)

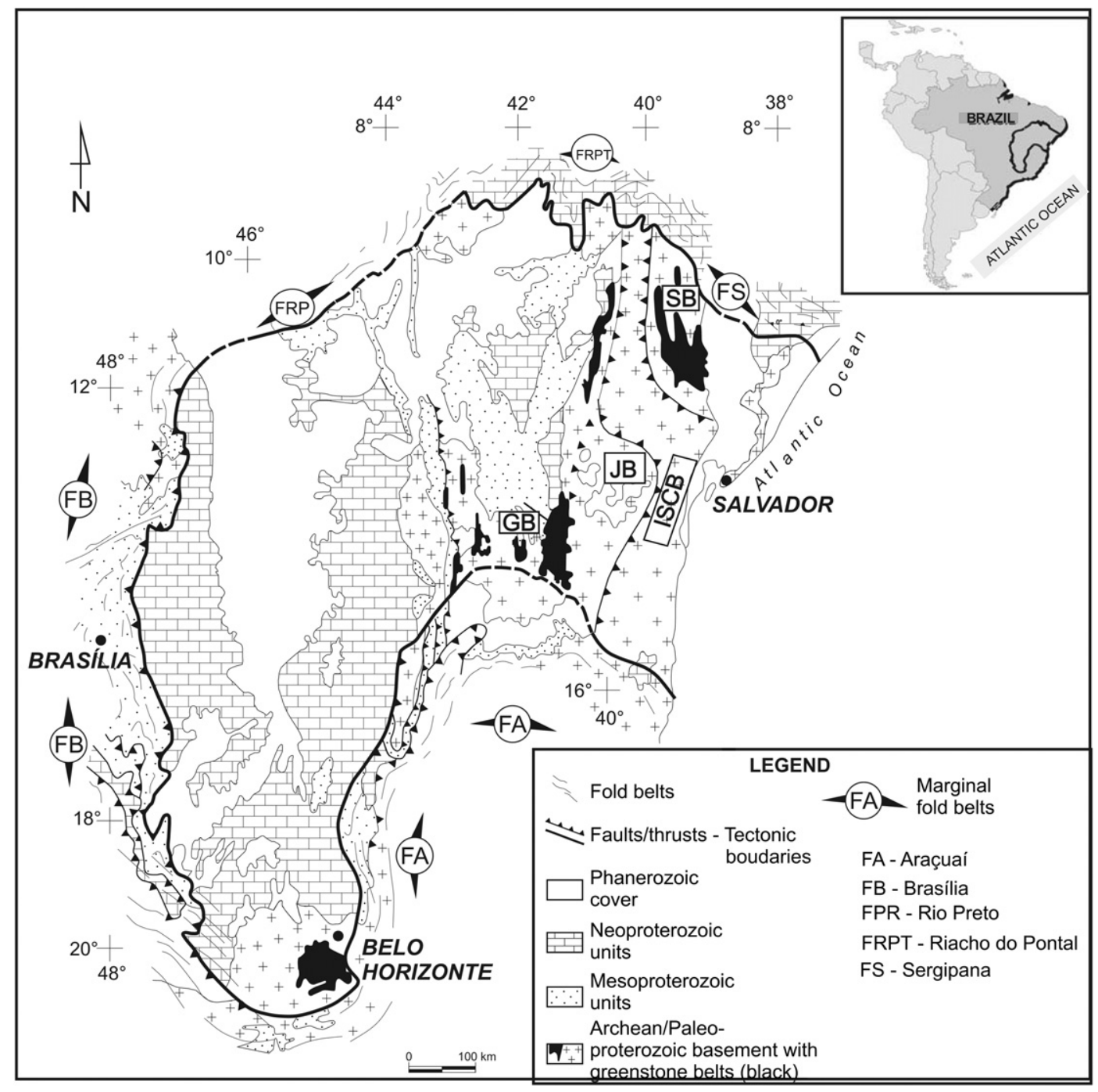

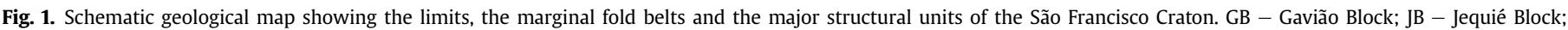
SB - Serrinha Block; ISCB - Itabuna-Salvador-Curaçá Block. The grey rectangle indicates the studied area. (Adapted from Alkmim et al., 1993). 
Paleoproterozoic tonalitic and trondhjemitic granulites (Silva et al., 2002; this work). In this area, the granulite facies metamorphism has been dated at 2.06-2.07 Ga (Ledru et al., 1994; Silva et al., 2002), with temperatures between 926 and $980 \pm 40{ }^{\circ} \mathrm{C}$, and at pressures of about $6.9-8.6 \pm 2 \mathrm{k}$ bar (Pinho, 2005).

The studied tonalitic and trondhjemitic granulites are tectonically interlayered with Archean enderbitic relics, monzonitic and syenitic granulites. They are represented in Fig. 2 as undifferentiated granulites. These rocks are dark grey, medium-grained and foliated. Mafic bodies, now parallel to the regional foliation, are found in these granulites. Based on their mineralogical composition, Pinho (2000) referred them as garnet-bearing mafic granulites. They are grey to dark grey, medium-grained, foliated or banded rocks.

The Geological evidence coupled with structural, metamorphic and isotopic data suggest a collision of these four crustal segments (GB, JB, SB, and ISCB) (Fig. 3A), during the Paleoproterozoic, resulting in the formation of an mountain belt with an N-S length of approximately $600 \mathrm{~km}$ and a mean E-W width of $150 \mathrm{~km}$. The traces of this collision are found not only in the structural features, but also by studying the pre-and syntectonic Paleoproterozoic rocks that are intruded into the above mentioned crustal segments, mainly in the Gavião Block (Marinho, 1991; Santos Pinto, 1996;
Bastos Leal et al., 2003), Itabuna-Salvador-Curaçá Block (Ledru et al., 1997; Barbosa et al., 2004) and Serrinha Block (Oliveira et al., 1999, 2000; Melo et al., 2000; Rios et al., 2005). During the sinistral collision, slices of the Jequié Block may have been incorporated in the Itabuna-Salvador-Curaçá Block.

\section{Petrography}

\subsection{Tonalitic and trondhjemitic granulites}

The tonalitic and trondhjemitic granulites are leucocratic to mesocratic rocks with inequigranular, interlobate to polygonal granoblastic textures. They mainly consist of a quartz and plagioclase (An43) association with minor amounts of orthopyroxene, clinopyroxene and opaque minerals. Perthitic K-feldspar is rare, and hornblende and biotite are retrograde minerals. The main accessory phases are apatite and zircon together with scarce crystals of allanite and garnet. Nevertheless, the size and textures of some plagioclase, quartz and pyroxene crystals indicate that they belonged to the original plutonic paragenesis that re-equilibrated during granulite metamorphism. Modal compositions (Table 1) plotted in the QAP diagram of Streckeisen (1976) fall in the tonalite and trondhjemite

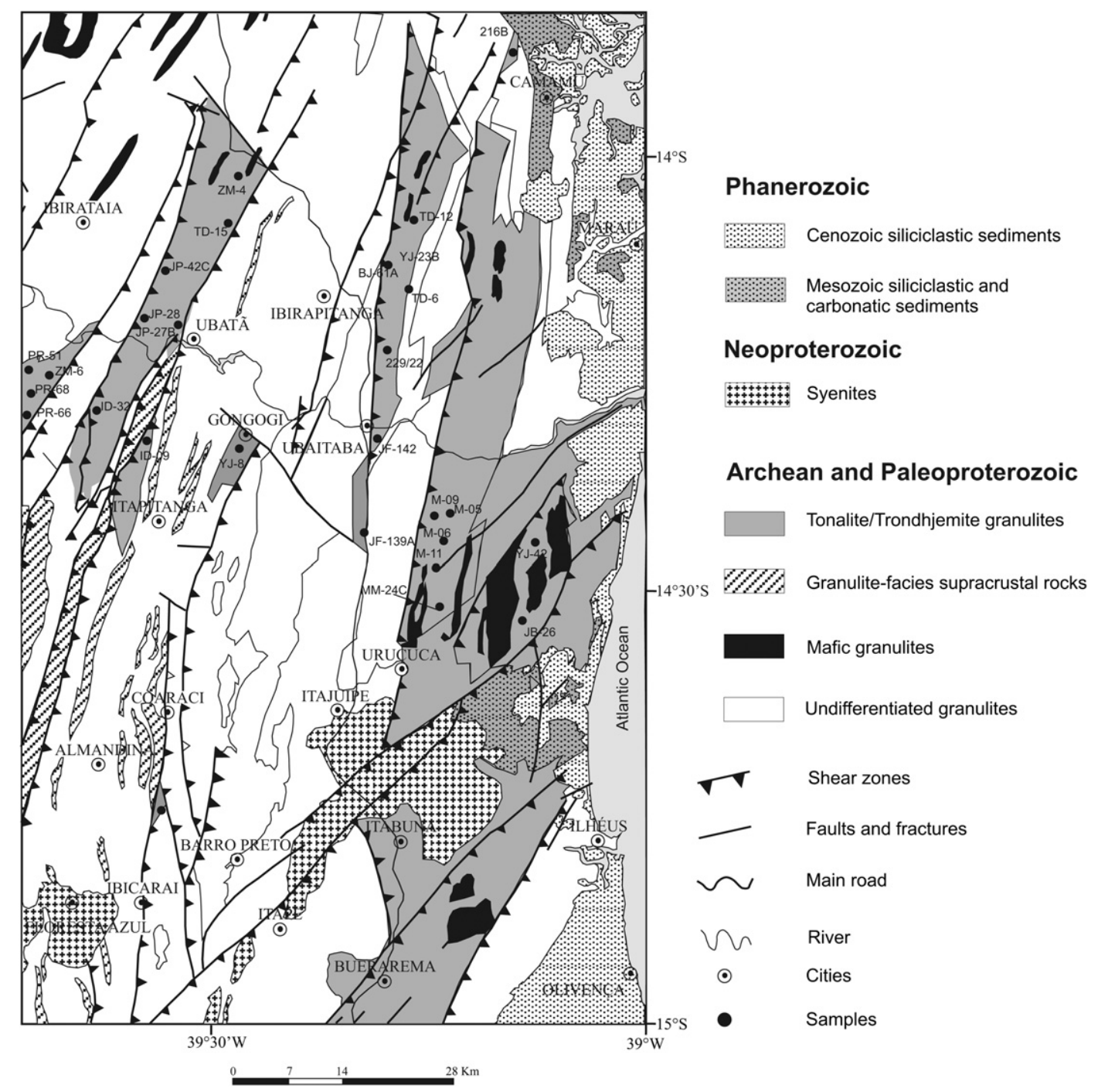

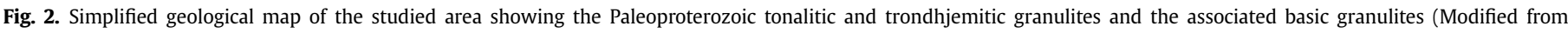
Barbosa, 1990). 

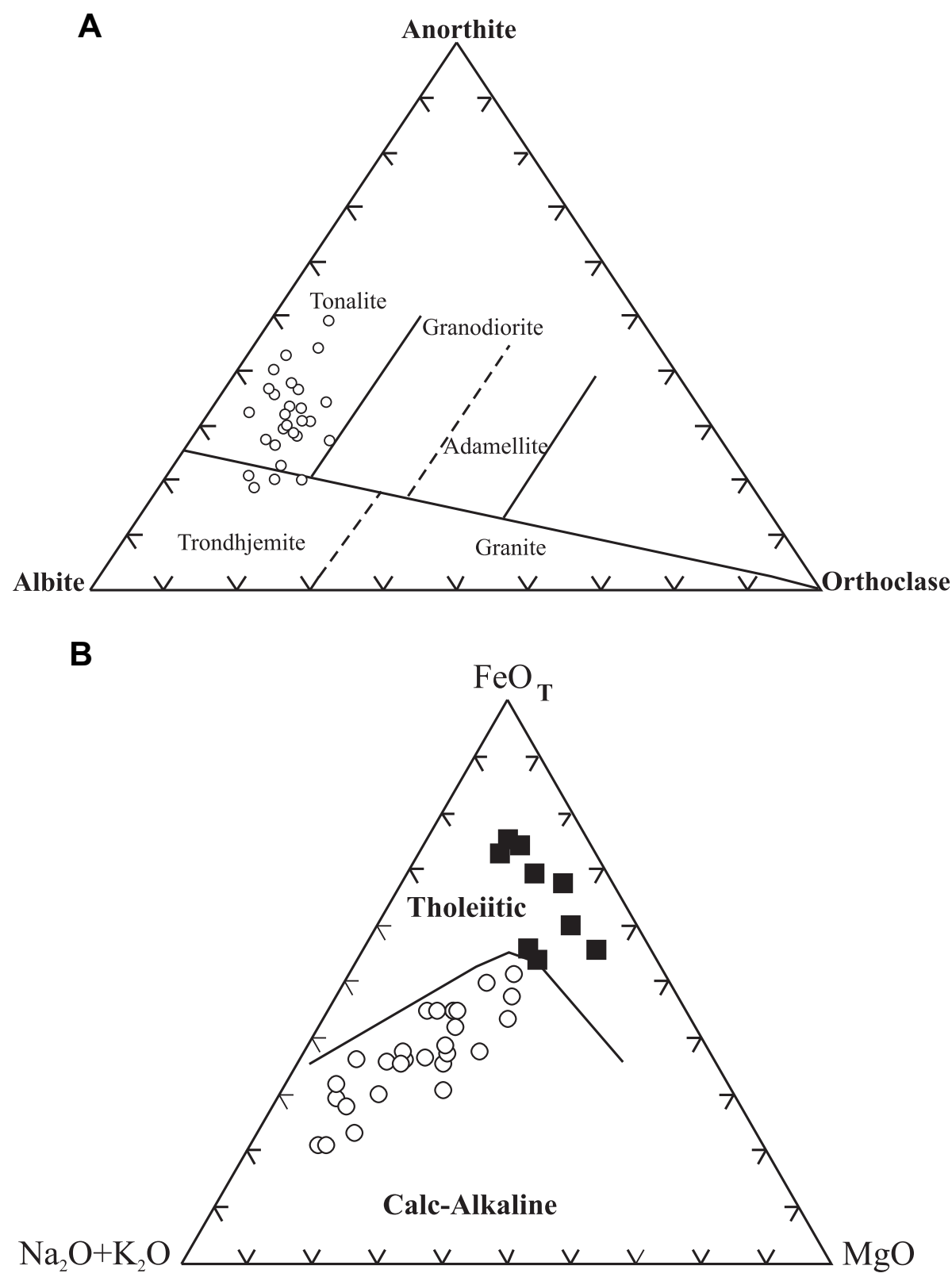

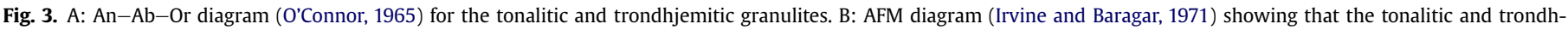
jemitic granulites (open circle) plot in the calc-alkaline field whereas the garnet-bearing basic granulites (filled squares) fall in the tholeiitic field.

field (Pinho, 2005). Microstructures such as wedge-shaped plagioclase with slightly bent albite twins, fractured quartz grains with undulose extinction, as well as fractured pyroxenes, show that the rocks underwent both ductile and brittle deformations after their emplacement. Their Sm-Nd TDM model ages vary from 2.8 Ga to $2.4 \mathrm{Ga}$, while zircon SHRIMP dates of $2119 \pm 10 \mathrm{Ma}$ and $2213 \pm 11 \mathrm{Ma}$ are interpreted as the age of different magmatic inputs. On the other hand, metamorphic zircon crystals yielded an age of $2083 \pm 17 \mathrm{Ma}$ (Peucat et al., in preparation).

\subsection{Garnet-bearing mafic granulites}

The mafic granulites are mesocratic with granoblastic textures. They are composed of plagioclase, clinopyroxene and orthopyroxene, together with garnet, quartz, opaque minerals, apatite and zircon as accessory minerals, and hornblende and biotite as secondary phases. Most of the rocks are gabbros, but some are quartz diorites (Table 2) (Pinho, 2005). Symplectitic and coronitic textures result from reactions between garnet, plagioclase, quartz and pyroxenes. Exsolution of orthopyroxene from clinopyroxene is also observed.

\section{Geochemical characteristics}

\subsection{Analytical methods}

Analyses of major, trace and rare earth elements were obtained in the laboratory of GEOSOL - Geologia e Sondagem S.A. Major elements, except for low concentrations of $\mathrm{Na}$ and $\mathrm{K}$, were obtained by X-ray fluorescence. Atomic absorbtion spectrophotometry was used to determine low concentrations of $\mathrm{Na}$ and $\mathrm{K} . \mathrm{Co}, \mathrm{Cr}, \mathrm{Cu}, \mathrm{Ni}, \mathrm{Pb}$, and REE were analyzed by ICP-OES after $\mathrm{HF}+\mathrm{HClO}_{4}$ digestion. $\mathrm{F}$ was 
Table 1

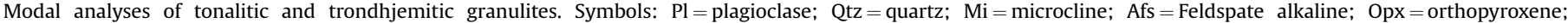
$\mathrm{Cpx}=$ clinopyroxene; $\mathrm{Hbl}=$ hornblende; $\mathrm{Bt}=$ biotite; $\mathrm{Grt}=$ garnet; $\mathrm{Mo}=$ opaque minerals; $\mathrm{Ap}=$ apatite; $\mathrm{Zr}=\mathrm{zircon}$.

\begin{tabular}{|c|c|c|c|c|c|c|c|c|c|c|c|c|}
\hline \multirow[t]{2}{*}{ Samples } & \multicolumn{12}{|c|}{ Modal Analyses (\%) } \\
\hline & $\mathrm{Pl}$ & Qtz & $\mathrm{Mi}$ & Afs & Opx & $\mathrm{Cpx}$ & $\mathrm{Hbl}$ & Bt & Grt & Mo & Ap & $\mathrm{Zr}$ \\
\hline TD-6 & 50 & 24.43 & - & - & - & 9.14 & - & 1.43 & 11.43 & 2 & 0.86 & 0.71 \\
\hline TD-12 & 56 & 15 & - & - & 11.71 & 11.86 & - & - & - & 3.29 & 1.43 & 0.71 \\
\hline TD-15 & 38.86 & 46.63 & - & - & 10.57 & - & - & 0.86 & - & 3 & - & 0.28 \\
\hline $\mathrm{BJ}-61 \mathrm{~A}$ & 41.3 & 45.71 & - & - & 1.14 & 2.71 & - & 4.86 & - & 3.43 & 0.71 & 0.14 \\
\hline ID-32 & 44.36 & 40.22 & - & - & 3.71 & 6 & - & 0.71 & - & 4 & 0.29 & 0.71 \\
\hline ZM-4 & 49.5 & 45.57 & - & - & - & - & - & - & - & 3.5 & 1.71 & 0.29 \\
\hline ZM-6 & 51.63 & 11.62 & - & - & 9.75 & 9.25 & 5.75 & 1.25 & 4 & 2.62 & 0.13 & - \\
\hline JF-139A & 44 & 29.15 & - & - & 9.71 & 9.71 & - & 3.14 & - & 3 & 0.86 & 0.43 \\
\hline JF-142A & 53.21 & 29.07 & - & - & 13.57 & - & - & 0.57 & - & 3 & 0.29 & 0.29 \\
\hline JP-27B & 31.71 & 45.02 & - & - & 8.14 & - & - & 7.71 & - & 3 & 0.14 & 0.28 \\
\hline JP-28 & 45.3 & 19.3 & - & - & 11 & - & 10.3 & 7.3 & - & 4 & 2 & 0.8 \\
\hline MM-24 & 45.2 & 47.05 & - & 1.25 & 2.6 & - & - & 0.75 & - & 1.2 & 0.05 & 0.15 \\
\hline PR-66 & 40.71 & 33.43 & - & - & 8.14 & 8.43 & - & 5.43 & - & 3 & 0.57 & 0.29 \\
\hline YJ-8 & 49 & 35 & - & 3 & 10 & - & - & - & - & 2 & - & 1 \\
\hline YJ-23B & 37.7 & 9.45 & - & & 21.65 & 16.5 & 4.95 & 0.35 & - & 7.6 & - & 1.80 \\
\hline ID-09 & 48.15 & 42.45 & - & - & 5 & - & - & 1 & - & 2 & - & 1 \\
\hline$J P-42 C$ & 49.57 & 35.14 & - & - & 8 & - & - & 3.43 & - & 3.14 & - & 0.29 \\
\hline
\end{tabular}

determined by specific ion electrode after alkaline fusion. The MINPET software (Richard, 1995) was used for preparation of graphics.

\subsection{Tonalitic and trondhjemitic granulites}

The tonalitic and trondhjemitic granulites display a wide range in both $\mathrm{SiO}_{2}(53-71 \%)$ and $\mathrm{MgO}(4.5-0.59)$ contents (Table 3). In the normative An-Ab-Or triangle of O'Connor (1965), where only samples with more than $10 \%$ normative quartz should be plotted, most samples fall in the tonalitic field, whereas only 4 are trondhjemites (Fig. 3A). From this point of view, they differ from Archean TTG sequences that are richer in Na and therefore rich in trondhjemites (Martin, 1994). In the AFM diagram of Irvine and Baragar (1971), all these granulites perfectly fall in the calc-alkaline domain where they define a smooth trend (Fig. 3B). In Harker diagrams all elements show differentiation trends and are negatively correlated with $\mathrm{SiO}_{2}$, except for $\mathrm{K}_{2} \mathrm{O}$ that is positively correlated, and $\mathrm{Na}_{2} \mathrm{O}$ which displays almost no variation during differentiation (Fig. 4).

The behaviour of $\mathrm{V}, \mathrm{Y}$ and $\mathrm{Zr}$ is that of compatible or partly compatible elements, while in spite of its concentrations $\mathrm{Sr}$ behaves as an incompatible element (Fig. 5). In a chondrite normalized diagram Light Rare Earth Elements (LREE) contents are enriched relative to Heavy Rare Earth Elements (HREE), thus resulting in high $(\mathrm{La} / \mathrm{Yb})_{\mathrm{N}}$ ratios $(11.5-75.0)$. The patterns lack significant Eu anomalies (Fig. 6), Eu/Eu* ratios ranging from 0.7 to 1.1 (Table 3). These characteristics are typical of Archean TTG (Martin et al.,
2005). In primitive mantle normalized multi-element diagrams (Fig. 7) all elements are enriched relative to primitive mantle. However, the degree of enrichment varies widely: LILE are more enriched $(10-100 \times)$ than HREE $(1-10 \times)$. Ba and $\mathrm{Zr}$ display positive anomalies, while $\mathrm{Sr}, \mathrm{Nb}, \mathrm{Ti}$ and $\mathrm{P}$ have negative anomalies. According to Martin (1999) the negative anomalies for the last three elements are common in Archean-Paleoproterozoic TTGs and are thought to result from fractionation of apatite and Fe-Ti oxide minerals during differentiation (Martin, 1999; Foley et al., 2000).

\subsection{Garnet-bearing mafic granulites}

The mafic granulites are MgO-poor (2.7\%-7.2\%) and $\mathrm{FeO}+\mathrm{Fe}_{2} \mathrm{O}_{3}$-rich (11.2\%-19.7\%; Table 4). In the AFM diagram (Irvine and Baragar, 1971), they plot in the tholeiite field, (Fig. 4B). REE patterns (Fig. 6) are moderately fractionated with $(\mathrm{La} / \mathrm{Yb})_{\mathrm{N}}$ ranging from 1.0 to 3.2, and no significant Eu anomaly is apparent with $\mathrm{Eu} / \mathrm{Eu}^{*}$ ranging between 0.78 and 0.97 . All these values are typical of tholeiitic magmas.

\section{Geochemical modelling}

\subsection{Mechanisms of differentiation}

Our approach is based only on the whole rock geochemistry, performed on samples of several $\mathrm{kg}$ in weight. Consequently, it is assumed that they represent the composition of the magma, and that granulitic metamorphism, was not able to change the whole

Table 2

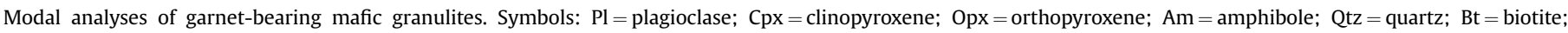
$\mathrm{Grt}=$ garnet; $\mathrm{Mo}=$ opaque minerals; $\mathrm{Ap}=$ apatite; $\mathrm{Zr}=$ zircon.

\begin{tabular}{|c|c|c|c|c|c|c|c|c|c|c|}
\hline \multirow[t]{2}{*}{ Samples } & \multicolumn{10}{|c|}{ Modal Analyses (\%) } \\
\hline & $\mathrm{Pl}$ & Cpx & Opx & Am & Qtz & Bt & Grt & Mo & Ap & $\mathrm{Zr}$ \\
\hline 216B & 45.00 & 20.00 & 18.00 & 4.00 & 4.00 & 1.00 & 3.00 & 5.00 & - & - \\
\hline JB-26 & 46.30 & 29.80 & - & 4.60 & 1.80 & - & 13.80 & 3.50 & 0.20 & - \\
\hline M-05 & 45.31 & 27.71 & 14.33 & 1.00 & 0.86 & 3.43 & 2.86 & 3.50 & 0.86 & 0.14 \\
\hline M-06 & 33.71 & 14.43 & 11.29 & 3.00 & 9.00 & 0.29 & 22.14 & 5.00 & 1.00 & 0.14 \\
\hline M-09 & 42.43 & 2.29 & 19.57 & - & 6.71 & - & 22.86 & 4.00 & 2.00 & 0.14 \\
\hline M-11 & 45.00 & 6.00 & 6.00 & - & 8.00 & - & 25.00 & 4.00 & - & - \\
\hline PR-51 & 43.28 & 21.43 & 24.00 & 5.86 & 1.86 & - & 0.43 & 3.00 & 0.14 & - \\
\hline PR-68 & 39.70 & 28.57 & - & 10.57 & 4.14 & - & 12.60 & 4.00 & 0.28 & 0.14 \\
\hline
\end{tabular}


Table 3

Representative major and trace element analyses of tonalitic and trondhjemitic granulites.

\begin{tabular}{|c|c|c|c|c|c|c|c|c|c|c|c|c|c|c|c|c|c|c|}
\hline Samples & TD-6 & TD-12 & ZM-4 & JF-142A & JF-139A & ZM-6 & PR-66 & TD-15 & JP-42C & JP-27B & JP-28 & ID-32 & YJ-23B & YJ-42 & MM-24C & YJ-8 & BJ-61A & ID-09 \\
\hline $\mathrm{SiO}_{2}$ & 53.2 & 59.70 & 59.80 & 60.20 & 60.40 & 62.20 & $\begin{array}{l}62.70 \\
\end{array}$ & 64.80 & 65.30 & 65.90 & 66.40 & 66.50 & 67.8 & 68.10 & 68.80 & 69.60 & 71.00 & 71.10 \\
\hline $\mathrm{TiO}_{2}$ & 1.00 & 0.78 & 0.91 & 0.54 & 0.73 & 0.89 & 0.72 & 0.61 & 0.63 & 0.45 & 0.49 & 0.54 & 0.35 & 0.37 & 0.13 & 0.55 & 0.34 & 0.28 \\
\hline $\mathrm{Al}_{2} \mathrm{O}_{3}$ & 17.8 & 16.10 & 16.10 & 19.10 & 16.90 & 16.00 & 16.20 & 15.10 & 15.80 & 15.40 & 16.10 & 15.10 & 12.1 & 15.30 & 17.00 & 14.10 & 13.80 & 14.70 \\
\hline $\mathrm{Fe}_{2} \mathrm{O}_{3}$ & 4.6 & 2.60 & 4.30 & 0.70 & 0.57 & 3.70 & 2.80 & 2.00 & 1.80 & 1.00 & 1.90 & 2.40 & 4.2 & 2.40 & 0.74 & 0.21 & 2.30 & 0.82 \\
\hline $\mathrm{FeO}$ & 5.00 & 4.30 & 3.80 & 3.60 & 4.80 & 3.10 & 3.10 & 4.10 & 3.70 & 3.90 & 2.80 & 2.90 & 2.6 & 1.30 & 2.10 & 4.40 & 1.80 & 2.40 \\
\hline MnO & 0.18 & 0.17 & 0.16 & 0.05 & 0.08 & 0.09 & 0.17 & 0.15 & 0.11 & 0.10 & 0.10 & 0.11 & 0.11 & 0.05 & 0.05 & 0.05 & 0.14 & 0.09 \\
\hline MgO & 4.50 & 3.30 & 2.60 & 2.00 & 3.20 & 3.00 & 3.00 & 2.00 & 2.60 & 3.20 & 1.80 & 1.70 & 2.40 & 1.20 & 1.00 & 1.80 & 0.59 & 0.92 \\
\hline $\mathrm{CaO}$ & 8.70 & 5.50 & 5.30 & 5.40 & 6.00 & 5.50 & 5.00 & 3.90 & 3.10 & 3.30 & 4.30 & 5.40 & 6.60 & 2.80 & 2.90 & 3.50 & 4.70 & 2.70 \\
\hline $\mathrm{Na}_{2} \mathrm{O}$ & 3.20 & 3.80 & 4.40 & 5.70 & 4.40 & 3.70 & 4.30 & 3.60 & 4.90 & 4.30 & 4.10 & 3.90 & 2.30 & 4.50 & 4.90 & 3.60 & 3.30 & 4.90 \\
\hline $\mathrm{K}_{2} \mathrm{O}$ & 0.90 & 2.50 & 1.60 & 1.60 & 1.60 & 1.60 & 1.20 & 2.70 & 1.20 & 1.50 & 1.20 & 0.57 & 0.49 & 2.10 & 1.70 & 1.90 & 0.93 & 1.40 \\
\hline $\mathrm{P}_{2} \mathrm{O}_{5}$ & 0.44 & 0.32 & 0.31 & 0.29 & 0.25 & 0.22 & 0.21 & 0.27 & 0.15 & 0.14 & 0.16 & 0.11 & 0.11 & 0.20 & 0.16 & 0.20 & 0.07 & 0.08 \\
\hline Total & 99.52 & 99.07 & 99.28 & 99.18 & 98.93 & 100.00 & 99.40 & 99.23 & 99.29 & 99.19 & 99.35 & 99.23 & 99.06 & 98.32 & 99.48 & 99.91 & 98.97 & 99.39 \\
\hline V & & & & & & 91 & 78 & & & & 58 & & 71 & 53 & & 58 & & 30 \\
\hline $\mathrm{Rb}$ & & & & 17 & 20 & 5 & 27 & 36 & & & 17 & 7 & 5 & 21 & & 5 & 16 & 22 \\
\hline $\mathrm{Ba}$ & 592 & 1348 & 684 & 880 & 840 & 2580 & 585 & 1131 & 750 & 445 & 493 & 367 & 208 & 788 & & 888 & 590 & 546 \\
\hline $\mathrm{Sr}$ & & 440 & & & 440 & 545 & 656 & 605 & 291 & & 540 & & 339 & 1022 & & 618 & 375 & 608 \\
\hline $\mathrm{Nb}$ & 6 & 13 & 12 & 20 & 20 & 13 & 5 & 7 & 9 & 9 & 9 & 13 & 6 & 8 & 10 & 8 & 5 & 6 \\
\hline $\mathrm{Hf}$ & 10 & 8 & 8 & & & & 8 & 8 & 10 & 8 & 8 & 8 & 10 & 8 & & & 8 & 8 \\
\hline $\mathrm{Zr}$ & & 250 & & 154 & & 228 & 127 & 196 & 440 & & 183 & & 74 & 131 & & 318 & 54 & 199 \\
\hline Y & & 20 & 20 & & & & & 17 & 23 & 20 & 11 & 15 & 20 & 21 & 10 & 19 & 13 & 7 \\
\hline $\mathrm{La}$ & 32.06 & 58.28 & 40.12 & 23.33 & 48.01 & 24.25 & 17.24 & 39.79 & 51.89 & 20.40 & 54.41 & 37.41 & 11.45 & 10.92 & 34.38 & 72.82 & 14.62 & 29.44 \\
\hline $\mathrm{Ce}$ & 74.67 & 130.00 & 73.53 & 46.70 & 92.83 & 43.15 & 38.24 & 78.56 & 108.90 & 47.93 & 98.20 & 74.04 & 23.93 & 21.64 & 71.70 & 125.80 & 30.13 & 56.66 \\
\hline Nd & 31.60 & 54.30 & 27.51 & 21.57 & 36.47 & 17.45 & 20.32 & 29.28 & 40.97 & 21.42 & 29.30 & 24.72 & 11.79 & 8.84 & 30.54 & 46.94 & 11.48 & 17.88 \\
\hline $\mathrm{Sm}$ & 6.18 & 9.06 & 4.59 & 3.44 & 5.66 & 3.63 & 3.17 & 4.86 & 5.94 & 3.86 & 4.38 & 4.48 & 2.81 & 1.68 & 4.73 & 7.95 & 2.10 & 2.50 \\
\hline Eu & 1.37 & 1.64 & 0.94 & 1.13 & 1.48 & 1.10 & 0.94 & 1.07 & 1.70 & 1.00 & 1.03 & 0.94 & 0.70 & 0.52 & 1.26 & 1.55 & 0.63 & 0.61 \\
\hline Gd & 4.43 & 4.56 & 2.47 & 2.29 & 3.55 & 2.47 & 2.04 & 2.72 & 3.92 & 3.04 & 2.61 & 3.02 & 2.38 & 1.55 & 2.39 & 5.04 & 1.32 & 1.68 \\
\hline Dy & 2.87 & 2.98 & 1.55 & 1.56 & 2.90 & 1.36 & 1.63 & 1.83 & 2.92 & 2.51 & 1.77 & 2.49 & 1.69 & 0.97 & 1.40 & 2.47 & 1.08 & 1.13 \\
\hline Ho & 0.56 & 0.56 & 0.27 & 0.32 & 0.64 & 0.27 & 0.32 & 0.34 & 0.58 & 0.47 & 0.33 & 0.50 & 0.39 & 0.20 & & 0.46 & 0.21 & 0.20 \\
\hline $\mathrm{Er}$ & 1.31 & 1.35 & 0.50 & 0.79 & 1.64 & 0.60 & 0.84 & 0.81 & 1.58 & 1.14 & 0.75 & 1.31 & 0.92 & 0.43 & 0.59 & 1.05 & 0.53 & 0.44 \\
\hline $\mathrm{Yb}$ & 0.86 & 0.82 & 0.29 & 0.53 & 1.24 & 0.42 & 0.58 & 0.51 & 1.38 & 0.90 & 0.48 & 0.98 & 0.66 & 0.26 & 0.44 & 0.64 & 0.45 & 0.31 \\
\hline $\mathrm{Lu}$ & 0.11 & 0.11 & 0.04 & 0.10 & 0.20 & 0.08 & 0.08 & 0.07 & 0.21 & 0.11 & 0.06 & 0.14 & 0.08 & 0.04 & 0.06 & 0.10 & 0.08 & 0.05 \\
\hline$(\mathrm{La} / \mathrm{Yb})_{\mathrm{N}}$ & 24.56 & 46.82 & 91.13 & 29.00 & 25.50 & 38.03 & 19.58 & 51.39 & 24.77 & 14.93 & 74.67 & 25.15 & 11.50 & 27.67 & 51.47 & 74.95 & 21.40 & 62.56 \\
\hline $\mathrm{Eu} / \mathrm{Eu}^{*}$ & 0.77 & 0.70 & 0.78 & 1.17 & 0.95 & 1.07 & 1.07 & 0.83 & 1.02 & 0.87 & 0.87 & 0.74 & 0.81 & 0.98 & 1.03 & 0.71 & 1.09 & 0.87 \\
\hline
\end{tabular}

$\mathrm{Eu} / \mathrm{Eu}^{*}=\mathrm{Eu}_{\mathrm{N}} /(\mathrm{Sm}+\mathrm{Gd})_{\mathrm{N}} / 2$. 

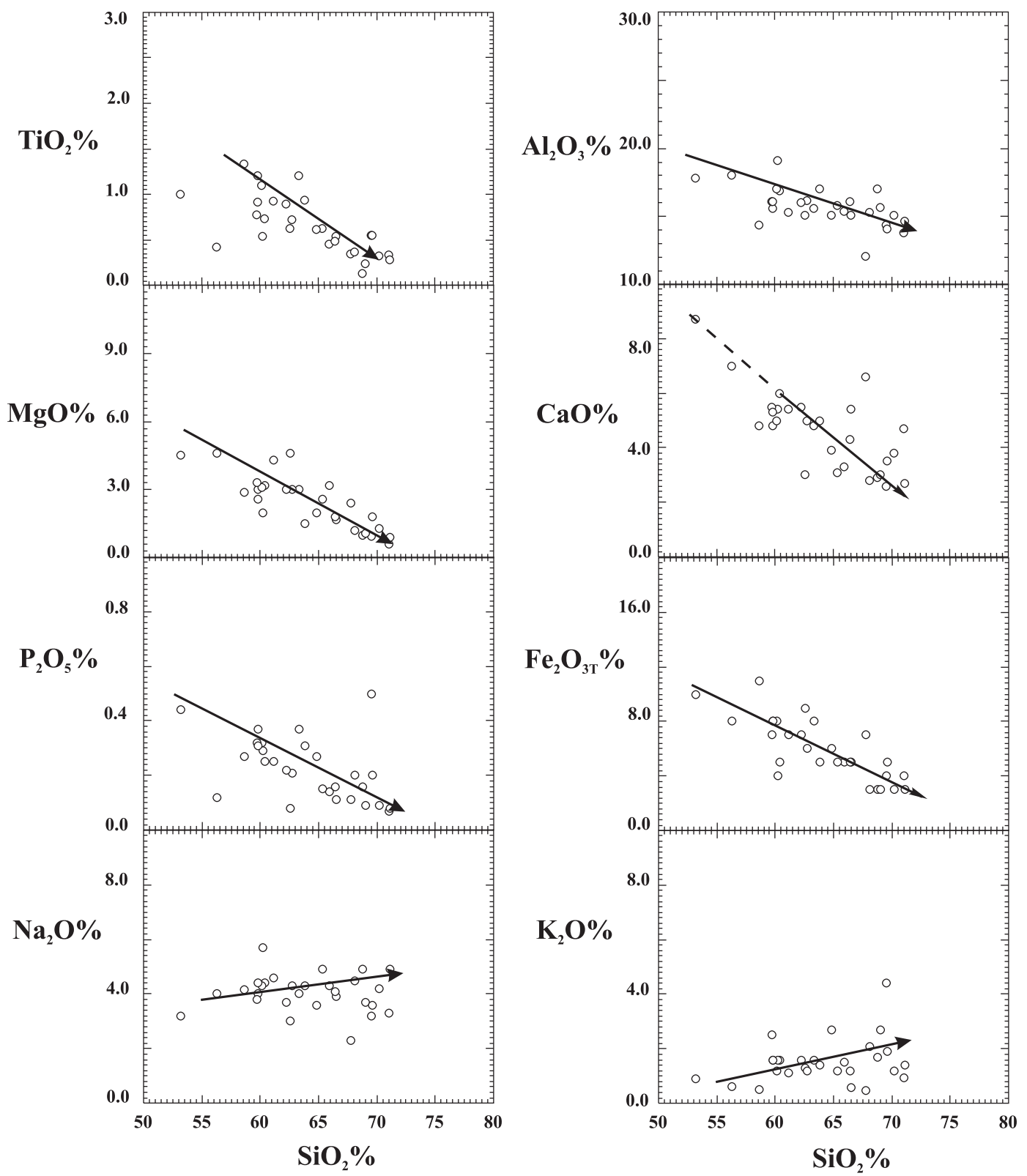

Fig. 4. Major element Harker (1909) diagrams for the tonalitic and trondhjemitic granulites.

rock composition. Such a metamorphism proceeds in the redistribution of chemical elements between old and/or new minerals, at a $\mathrm{cm}$ scale, but is unable to change the whole rock composition in large samples.

In the Harker diagrams for major and trace elements the Paleoproterozoic tonalitic and trondhjemitic granulites have trends which are usually straight lines but are sometimes curves ( $\mathrm{MgO}$, $\mathrm{P}_{2} \mathrm{O}_{5}, \mathrm{TiO}_{2}$ ). These curves demonstrate that the process which produced the trends cannot be mixing or mingling, which should strictly give straight trends. Consequently, the petrogenetic processes involved in tonalitic and trondhjemitic granulite genesis is either partial melting or fractional crystallization.

In Fig. 5 the behaviour of $\mathrm{Sr}$ is an incompatible element, while V, $\mathrm{Y}$ and in part $\mathrm{Zr}$ behave as compatible elements or partly compatible elements. In spite of the relative scattering of $\mathrm{Sr}$ data, in logscale diagrams of a compatible element ( $\mathrm{V}$ or $\mathrm{Zr}$ ) versus an incompatible element $(\mathrm{Sr})$ the trends observed are steep-sloped lines typical of fractional crystallization (Fig. 8). They do not show any sign of the horizontal trend that should result from partial melting. Consequently, in order to account for the trends observed in Harker diagrams, we will first attempt to quantify fractional crystallization in the tonalitic and trondhjemitic suite.

To perform the geochemical modelling we used the Genesis software of Teixeira (1997).

In a first step, the process is modelled using mass balance calculations based only on major elements (Stormer and Nicholls, 1978 ) to yield the modal and chemical compositions of the cumulate and the degree of fractional crystallization. In the second step, these computed values are entered into trace-element models using the Rayleigh (1896) equation.

The compositions of mineral phases used for our geochemical modelling are those included in the Genesis software (Teixeira, 1997) and the results obtained are shown in Table 5. The natural sample TD-12 that is the least differentiated (lower $\mathrm{SiO}_{2}$ and higher 

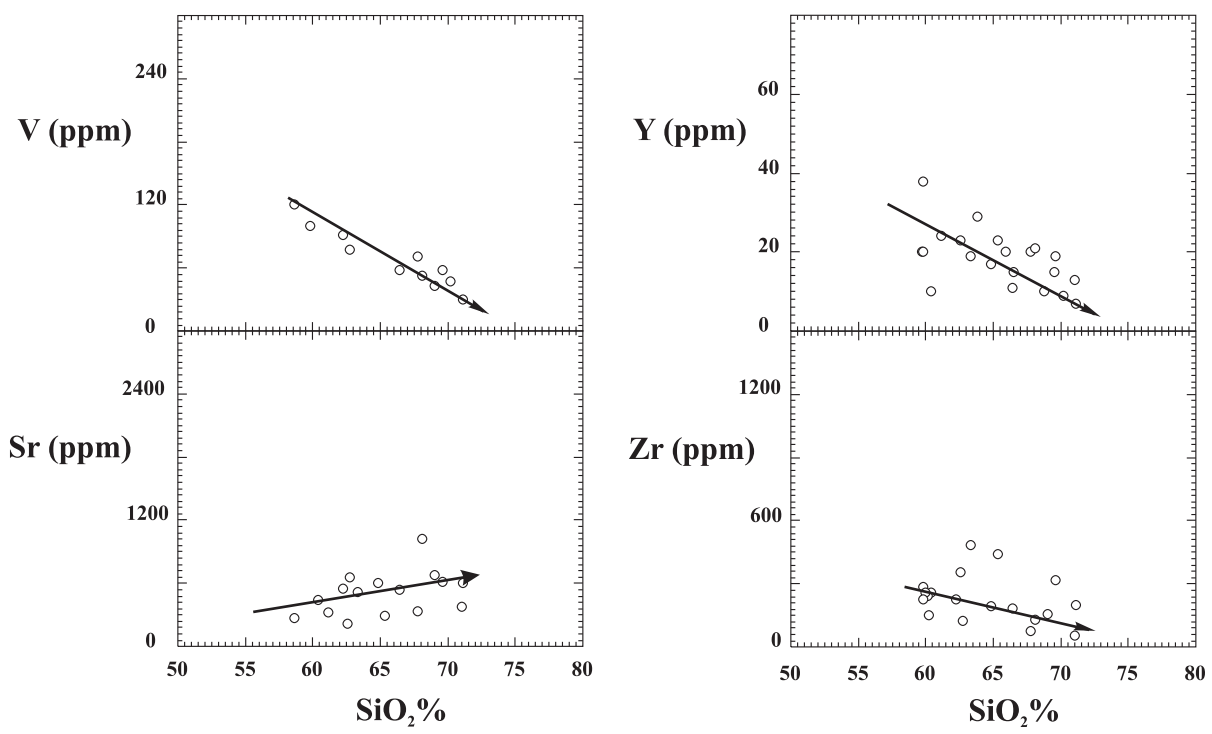

Fig. 5. Trace element Harker (1909) diagrams for tonalitic and trondhjemitic granulites.

$\mathrm{MgO}$ contents) is considered as the representative of the parental magma. Sample $\mathrm{BJ}-61 \mathrm{~A}$ having the higher $\mathrm{SiO}_{2}$ and lower $\mathrm{MgO}$ contents is assumed to represent the most differentiated magma. The computed cumulate contains plagioclase $\mathrm{An}_{43}$ $(46 \%)+$ hornblende $(29 \%)+$ biotite $(22 \%)+$ ilmenite $(1.6 \%)+$ apatite (1.4\%). This cumulate probably represents a residue of partial melting of aluminous basic rocks that after metamorphosed to

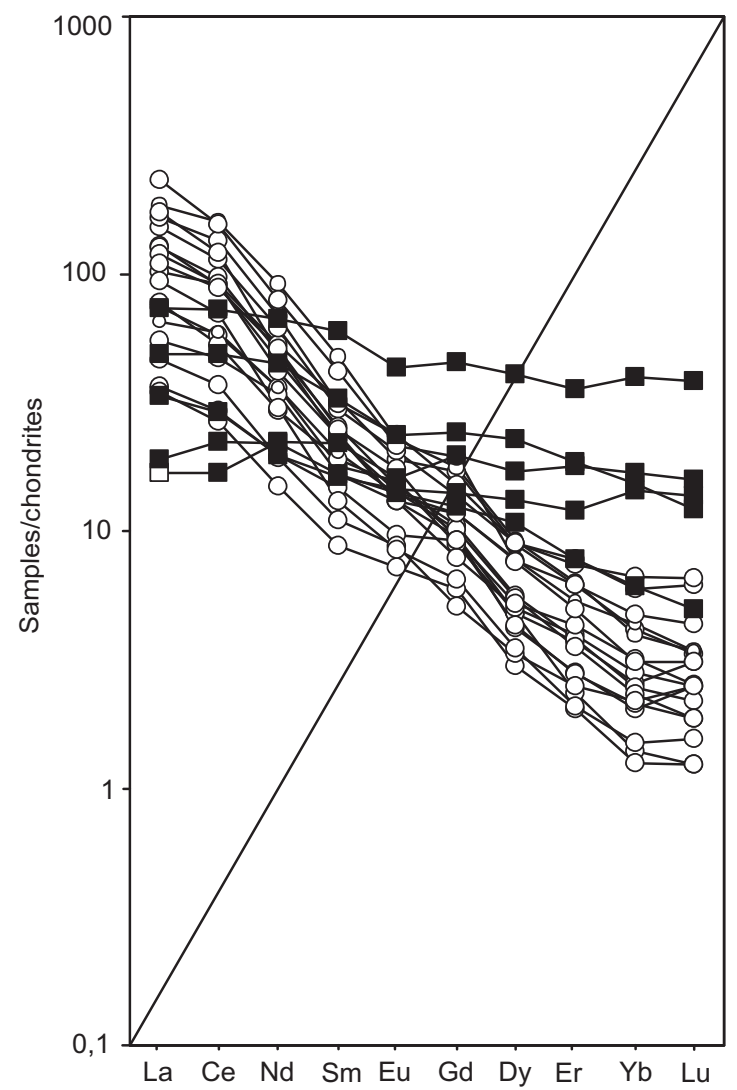

Fig. 6. Chondrite normalized (Masuda et al., 1973) REE pattern for the tonalitic and trondhjemitic granulites and the garnet-bearing mafic granulites. a great degree, produced the garnet-bearing mafic granulite. The sum of squared residues (SSR: 0.54 ) shows that the model closely fits the analytical data, the main contribution to SSR being due to the alkali oxides, especially $\mathrm{K}_{2} \mathrm{O}$. The degree of fractional crystallization is about $52 \%$.

The modal and chemical compositions of the cumulate, as well as the degree of fractionation calculated from major-element data, are now used in trace-element modelling. The mineral/liquid partition coefficients $\left(\mathrm{Kd}^{\mathrm{m} / \mathrm{l}}\right)$ were taken from literature compilations (Martin, 1987; Rollinson, 1993) (Table 6).

When the cumulate composition and the degree of fractionation calculated from major-element data are used in REE modelling, the model does not fit the analytical data at all. Consequently, it was assumed that accessory phases could have played a significant role. Fig. 5 shows that $\mathrm{Zr}$ is compatible. As zircon is quite abundant (but still an accessory mineral) in the tonalitic and trondhjemitic granulites, it could have participated in the fractional crystallization. The same can be done with LREE which may be fractionated by an LREE-rich phase such as allanite that is present in subordinate amounts in the studied rocks. We note that allanite is a widespread accessory phase in all Archean and Paleoproterozoic tonalites and

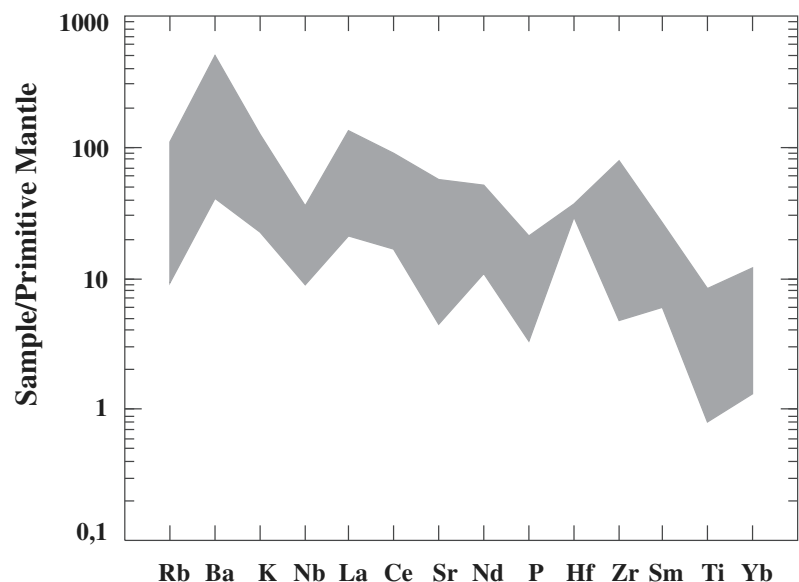

Fig. 7. Primitive-mantle normalized (Taylor and McLennan, 1985; Sun, 1980; Thompson, 1982) multi-element diagram for the tonalitic and trondhjemitic granulites. 
Table 4

Representative major and trace element analyses of garnet-bearing mafic granulites.

\begin{tabular}{|c|c|c|c|c|c|c|c|c|}
\hline Sample & 216B & JB-26 & PR-51 & PR-68 & M-05 & M-06 & M-11 & M-09 \\
\hline $\mathrm{SiO}_{2}$ & 45.54 & 47.50 & 48.90 & 49.40 & 50.21 & 50.56 & 51.92 & 53.46 \\
\hline $\mathrm{TiO}_{2}$ & 0.52 & 1.80 & 1.50 & 2.50 & 1.31 & 2.50 & 2.66 & 2.13 \\
\hline $\mathrm{Al}_{2} \mathrm{O}_{3}$ & 19.08 & 14.20 & 14.20 & 14.00 & 14.59 & 12.40 & 14.17 & 12.92 \\
\hline $\mathrm{Fe}_{2} \mathrm{O}_{3}$ & 5.31 & 6.00 & 3.10 & 2.60 & 1.06 & 4.34 & 1.05 & 0.66 \\
\hline $\mathrm{FeO}$ & 6.65 & 11.30 & 10.40 & 13.70 & 10.22 & 15.42 & 15.11 & 16.17 \\
\hline $\mathrm{MnO}$ & 0.22 & 0.24 & 0.20 & 0.25 & 0.20 & 0.33 & 0.33 & 0.31 \\
\hline $\mathrm{MgO}$ & 7.21 & 5.90 & 6.30 & 4.60 & 5.51 & 3.13 & 3.16 & 2.69 \\
\hline $\mathrm{CaO}$ & 11.86 & 9.70 & 12.10 & 9.70 & 11.06 & 7.81 & 6.37 & 7.03 \\
\hline $\mathrm{Na}_{2} \mathrm{O}$ & 1.25 & 1.60 & 2.30 & 2.20 & 2.74 & 2.61 & 1.93 & 2.51 \\
\hline $\mathrm{K}_{2} \mathrm{O}$ & 0.37 & 0.18 & 0.07 & 0.30 & 0.80 & 0.42 & 0.38 & 0.71 \\
\hline $\mathrm{P}_{2} \mathrm{O}_{5}$ & 0.03 & 0.40 & 0.13 & 0.31 & 0.44 & 0.76 & 0.71 & 0.80 \\
\hline Total & 98.04 & 98.82 & 99.20 & 99.56 & 98.14 & 100.28 & 97.79 & 99.39 \\
\hline $\mathrm{Cr}$ & 41 & 60 & 124 & 66 & & & & \\
\hline $\mathrm{Ni}$ & 40 & 61 & 81 & 19 & 15 & 14 & 2 & 2 \\
\hline Co & 32 & 27 & 47 & 41 & & & & \\
\hline V & 249 & 270 & 292 & 381 & & & & \\
\hline $\mathrm{Cu}$ & 71 & 156 & & & 40 & 54 & 194 & 45 \\
\hline $\mathrm{Rb}$ & 15 & 155 & 9 & 8 & 18 & 18 & 2 & 2 \\
\hline $\mathrm{Ba}$ & 86 & 5 & 31 & 147 & 1540 & 15 & & 141 \\
\hline $\mathrm{Sr}$ & 246 & 735 & 172 & 76 & 780 & 780 & 298 & 184 \\
\hline $\mathrm{Nb}$ & & 10 & 5 & 5 & & & & \\
\hline $\mathrm{Zr}$ & 75 & 115 & 83 & 66 & 145 & 215 & 117 & 210 \\
\hline Y & & 10 & 16 & 22 & & & & \\
\hline $\mathrm{La}$ & & 5.31 & 5.95 & 15.43 & & 23.11 & & \\
\hline $\mathrm{Ce}$ & & 13.60 & 18.04 & 39.79 & & 59.16 & & \\
\hline Nd & & 13.26 & 13.16 & 26.87 & & 39.95 & & \\
\hline $\mathrm{Sm}$ & & 4.19 & 3.17 & 6.27 & & 11.46 & & \\
\hline $\mathrm{Eu}$ & & 1.16 & 1.01 & 1.70 & & 3.12 & & \\
\hline Gd & & 5.07 & 3.21 & 6.29 & & 11.74 & & \\
\hline Dy & & 5.54 & 3.49 & 7.39 & & 13.14 & & \\
\hline Ho & & & 0.67 & 1.47 & & & & \\
\hline $\mathrm{Er}$ & & 3.79 & 1.65 & 3.95 & & 7.59 & & \\
\hline $\mathrm{Yb}$ & & 3.47 & 1.26 & 3.15 & & 8.27 & & \\
\hline $\mathrm{Lu}$ & & 0.51 & 0.16 & 0.39 & & 1.23 & & \\
\hline$\Sigma$ ETR & & 55.9 & 51.1 & 112.70 & & 178.77 & & \\
\hline $\mathrm{La} / \mathrm{YbN}$ & & 1.01 & 3.12 & 3.23 & & 1.85 & & \\
\hline $\mathrm{Eu} / \mathrm{Eu}^{*}$ & & 0.78 & 0.97 & 0.83 & & 0.82 & & \\
\hline
\end{tabular}

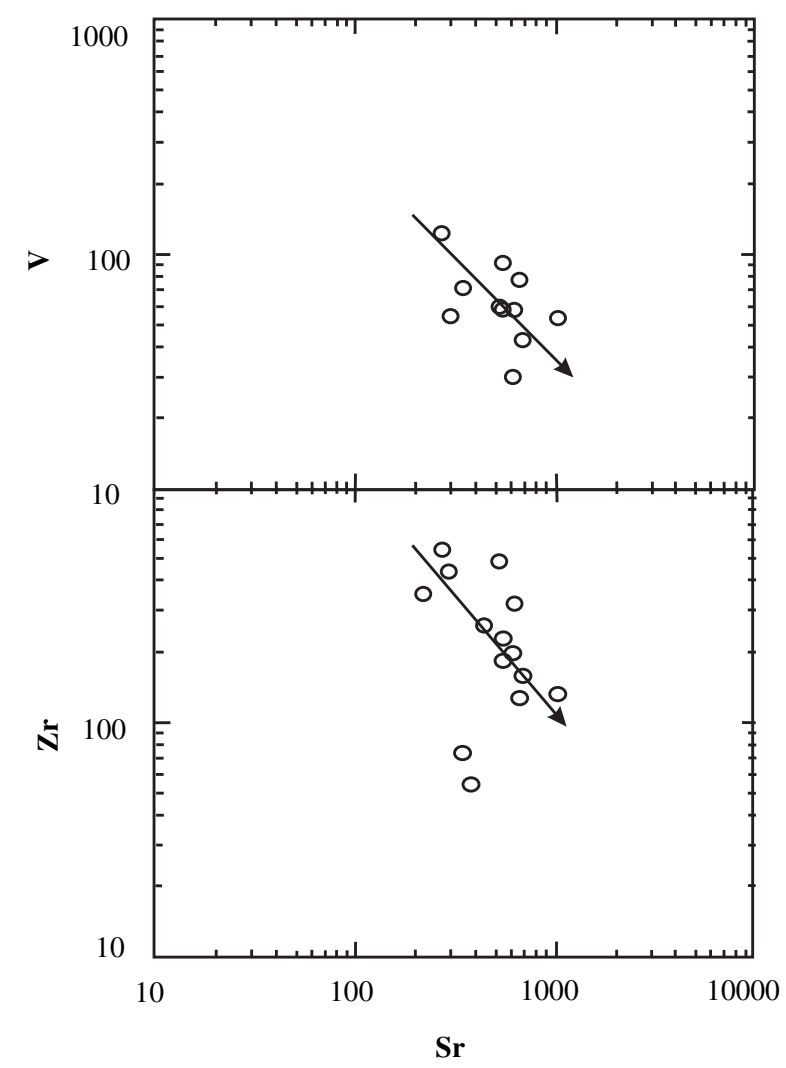

Fig. 8. Log compatible ( $\mathrm{V}$ and $\mathrm{Zr}$ ) versus log incompatible $(\mathrm{Sr})$ elements. The smooth almost vertical curves show that fractional crystallization was the prominent process of differentiation of the studied tonalitic and trondhjemitic granulites.
Table 5

Comparison of the major, trace and REE elements compositions of computed differentiated magma $(\mathrm{Cl})$ and the model differentiated magma $(\mathrm{Cl}=\mathrm{BJ}-61 \mathrm{~A})$. The composition of the parental magma $(\mathrm{Co}=\mathrm{TD}-12)$ is also given as well as the mineralogical composition of the extracted cumulate. The best fit is obtained for $52 \%$ fractional crystallization.

\begin{tabular}{|c|c|c|c|}
\hline \% Oxyde & $\begin{array}{l}\text { Parental magma } \\
\text { Co }=\text { TD- } 12\end{array}$ & $\begin{array}{l}\text { Differentiated } \\
\text { magma } \\
\mathrm{Cl}=\mathrm{BJ}-61-\mathrm{A}\end{array}$ & $\begin{array}{l}\text { Computed } \\
\text { differentiated } \\
\text { magma } \mathrm{Cl}\end{array}$ \\
\hline $\mathrm{SiO}_{2}$ & 59.7 & 71.0 & 71.06 \\
\hline $\mathrm{TiO}_{2}$ & 0.78 & 0.34 & 0.37 \\
\hline $\mathrm{Al}_{2} \mathrm{O}_{3}$ & 16.1 & 13.8 & 13.65 \\
\hline FeOtot & 7.16 & 4.3 & 4.27 \\
\hline $\mathrm{MgO}$ & 3.3 & 0.59 & 0.53 \\
\hline $\mathrm{CaO}$ & 5.5 & 4.7 & 4.22 \\
\hline $\mathrm{Na}_{2} \mathrm{O}$ & 3.8 & 3.3 & 3.52 \\
\hline $\mathrm{K}_{2} \mathrm{O}$ & 2.5 & 0.93 & 1.78 \\
\hline $\mathrm{P}_{2} \mathrm{O}_{5}$ & 0.32 & 0.02 & 0.06 \\
\hline \multicolumn{4}{|l|}{ ppm } \\
\hline La & 58.28 & 14.62 & 14.35 \\
\hline $\mathrm{Ce}$ & 130.00 & 30.13 & 28.62 \\
\hline Nd & 54.30 & 11.48 & 10.81 \\
\hline $\mathrm{Sm}$ & 9.06 & 2.10 & 1.87 \\
\hline $\mathrm{Eu}$ & 1.64 & 0.63 & 0.68 \\
\hline Gd & 4.56 & 1.32 & 1.04 \\
\hline Dy & 2.98 & 1.08 & 0.98 \\
\hline $\mathrm{Er}$ & 1.35 & 0.53 & 0.58 \\
\hline $\mathrm{Yb}$ & 0.82 & 0.45 & 0.38 \\
\hline $\mathrm{Nb}$ & 13 & 5 & 9 \\
\hline $\mathrm{Sr}$ & 440 & 375 & 382 \\
\hline $\mathrm{Zr}$ & 250 & 54 & 58 \\
\hline \multicolumn{4}{|c|}{ \% Mineral in cumulate } \\
\hline Plagioclase $\mathrm{An}_{43}$ & 46 & & \\
\hline Hornblende & 29 & & \\
\hline Biotite & 22 & & \\
\hline Ilmenite & 1.6 & & \\
\hline Apatite & 1.4 & & \\
\hline$\left(\Sigma D^{2}\right)=0.54$ & & & $X=(1-F)=52 \%$ \\
\hline
\end{tabular}

trondhjemites (Martin, 1987). Table 5 and Fig. 9 shows the result of REE modelling. The calculated amounts of cumulative zircon and allanite necessary to adjust the model to data are very small: $0.06 \%$ and $0.3 \%$ respectively. The calculated Eu content is higher than in the natural sample BJ-61A, thus defining a small positive anomaly. Contrary to most REE behaviour, $\mathrm{Kd}^{\text {mineral/liquid }}$ values for $\mathrm{Eu}$ in minerals such as feldspars are very sensitive to oxygen fugacity. A small change in this parameter would significantly change the partition of $\mathrm{Eu}$, but as we have no real constraints on these parameters we made no attempt to adjust the model further.

\subsection{Magmatic sources}

Modelling of fractional crystallization shows that sample TD-12 can be considered as representative of the parental magma of the

Table 6

Partition coefficients (Kd) used in the modelling of tonalites/trondhjemites granulites (Martin, 1987; Rollinson, 1993).

\begin{tabular}{clllllc}
\hline & Hornblende & Plagioclase & Magnetite & Allanite & Apatite & Zircon \\
\hline $\mathrm{La}$ & 0.2 & 0.32 & 0.22 & 960 & 25 & 2.0 \\
$\mathrm{Ce}$ & 0.3 & 0.22 & 0.26 & 940 & 35 & 2.64 \\
$\mathrm{Nd}$ & 0.8 & 0.15 & 0.3 & 750 & 58 & 2.2 \\
$\mathrm{Sm}$ & 1.1 & 0.1 & 0.35 & 620 & 64 & 3.14 \\
$\mathrm{Eu}$ & 1.3 & 1.21 & 0.26 & 56 & 30 & 3.14 \\
$\mathrm{Gd}$ & 1.8 & 0.067 & 0.28 & 440 & 64 & 12 \\
$\mathrm{Dy}$ & 2.0 & 0.05 & 0.28 & 200 & 58 & 101.5 \\
$\mathrm{Er}$ & 1.9 & 0.045 & 0.22 & 100 & 40 & 135 \\
$\mathrm{Yb}$ & 1.7 & 0.041 & 0.18 & 54 & 22 & 527 \\
$\mathrm{Nb}$ & 0.5 & 0.025 & 0.00001 & 1.0 & 0.00001 & 140 \\
$\mathrm{Sr}$ & 0.6 & 4.4 & 0.00001 & 0.00001 & 0.00001 & 0.00001 \\
$\mathrm{Zr}$ & 0.044 & 0.5 & 0.00001 & 0.00001 & 0.01 & 3800 \\
$\mathrm{Y}$ & 2.5 & 0.06 & 0.00001 & 1.0 & 0.00001 & 3800 \\
\hline
\end{tabular}




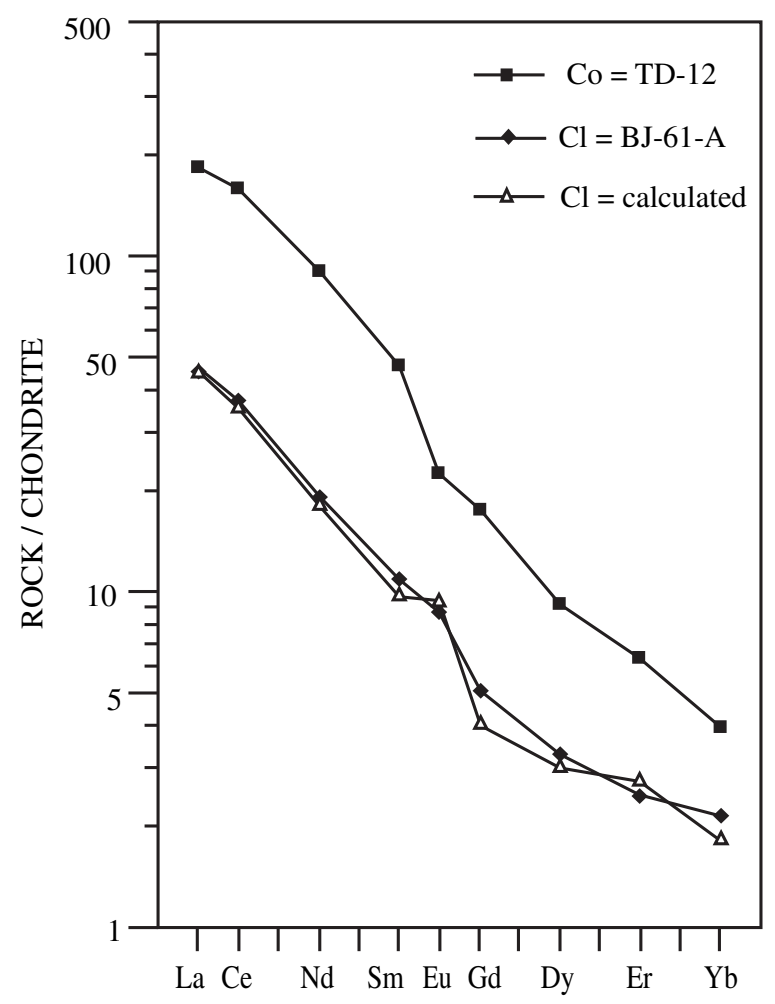

Fig. 9. Chondrite normalized (Masuda et al., 1973) REE pattern showing the result of the modelling of fractional crystallization of BJ-61A from TD-12.

Table 7

Comparison of the major, traces e ETR elements compositions of computed melt composition ( $\mathrm{Cl}$ ) and melt composition (TD-12). The composition of the solid source (average garnet granulite) is also given as well as the mineralogical composition of the residue of melting. The best fit is obtained for $20 \%$ partial melting. Batch melting equation of Shaw (1970): $C_{l}=C_{0} / F\left[1-(1-F)^{1 / D}\right]$ where $C_{L}=$ concentration of the element in the liquid, $C_{0}=$ concentration of the element in the solid source; $\mathrm{F}=$ degree of melting; and $\mathrm{D}=$ bulk partition coefficient.

\begin{tabular}{|c|c|c|c|}
\hline \% Oxvde & $\begin{array}{l}\text { Solid source average } \\
\text { garnet granulite }\end{array}$ & $\begin{array}{l}\text { Melt composition } \\
\text { TD-12 }\end{array}$ & $\begin{array}{l}\text { Computed melt } \\
\text { composition } \mathrm{Cl}\end{array}$ \\
\hline $\mathrm{SiO}_{2}$ & 50.44 & 59.7 & 59.72 \\
\hline $\mathrm{TiO}_{2}$ & 1.72 & 0.78 & 0.62 \\
\hline $\mathrm{Al}_{2} \mathrm{O}_{3}$ & 14.78 & 16.1 & 16.87 \\
\hline $\mathrm{FeO}$ & 15.15 & 7.16 & 7.18 \\
\hline $\mathrm{MgO}$ & 4.93 & 3.3 & 3.44 \\
\hline $\mathrm{CaO}$ & 9.18 & 5.5 & 5.68 \\
\hline $\mathrm{Na}_{2} \mathrm{O}$ & 2.14 & 3.8 & 3.82 \\
\hline $\mathrm{K}_{2} \mathrm{O}$ & 0.65 & 2.5 & 2.69 \\
\hline \multicolumn{4}{|l|}{ ppm } \\
\hline $\mathrm{La}$ & 12.07 & 58.28 & 57.1 \\
\hline $\mathrm{Ce}$ & 30.8 & 130 & 131.7 \\
\hline $\mathrm{Nd}$ & 21 & 54.30 & 68.0 \\
\hline $\mathrm{Sm}$ & 5.64 & 9.06 & 11.91 \\
\hline $\mathrm{Eu}$ & 1.6 & 1.64 & 2.19 \\
\hline Gd & 5.99 & 4.56 & 5.98 \\
\hline Dy & 6.77 & 2.98 & 3.1 \\
\hline $\mathrm{Er}$ & 3.91 & 1.35 & 1.26 \\
\hline $\mathrm{Yb}$ & 3.83 & 0.82 & 0.99 \\
\hline $\mathrm{Nb}$ & 6.66 & 13 & 13.2 \\
\hline $\mathrm{Sr}$ & 349 & 440 & 465 \\
\hline $\mathrm{Zr}$ & 119 & 250 & 284 \\
\hline \multicolumn{4}{|c|}{ \% Mineral in residue } \\
\hline Plagioclase & 26 & & \\
\hline Clinopyroxene & 19 & & \\
\hline Garnet & 21 & & \\
\hline Orthopyroxene & 19 & & \\
\hline Hornblende & 10 & & \\
\hline Opaque & 5 & & \\
\hline$\left(\Sigma D^{2}\right)=0.4$ & & & $F=20 \%$ \\
\hline
\end{tabular}

tonalitic and trondhjemitic suite. Consequently, the question now is to know how this parental magma could have been generated. Due to the low $\mathrm{SiO}_{2}$ and high $\mathrm{MgO}$ contents of TD-12, it can be concluded that this magma cannot be generated by recycling of a felsic crustal source. Here too, as for fractional crystallization modelling, calculations were performed initially with two compositions: the first one located between spinel lherzolite xenolith (peridotite KLB-1C) from Takahashi (1986), and a molten basalt from Rapp et al. (1999) and the second, located between the spinel lherzolhite xenolith (peridotite KLB-1C) from Takahashi (1986) and adakite (Zamora, 2000).The results of the calculation of mass balance with resolution of major elements, considering the two compositions discussed above, were quite satisfactory. However, when modelled the rare earth elements, using these two compositions, the results between the real and the calculated model were totally unsatisfactory. Due to the impossibility of setting the rare earth elements, all these possibilities were discarded. Then, the third model tested had as basis the average composition of the garnet-bearing granulite which occurs as enclaves within tonalitic-trondhjemitic granulites, and was chosen as a possible source.

The calculated modal composition of the residue consists of plagioclase $(26 \%)+$ garnet $(21 \%)+$ clinopyroxene $(19 \%)+$ orthopyroxene $(19 \%)+$ hornblende $(10 \%)+$ magnetite $(5 \%)$. The degree of melting $(F)$ is $20 \%$, and $\left(\Sigma D^{2}\right)=0.4$ (Table 7$)$. The REE and other trace element behaviour has been modelled using the batch melting equation of Shaw (1970). Fig. 10 and Table 7 shows the results of REE behaviour modelling. The figure shows that the computed model fits the TD-12 REE composition for both LREE and HREE, whereas it predicts slightly higher amounts of MREE. This could reflect the presence of small amounts of residual apatite, which would also account for the lower $\mathrm{P}_{2} \mathrm{O}_{5}$ content of TD-12 when compared with average garnet-bearing granulite.

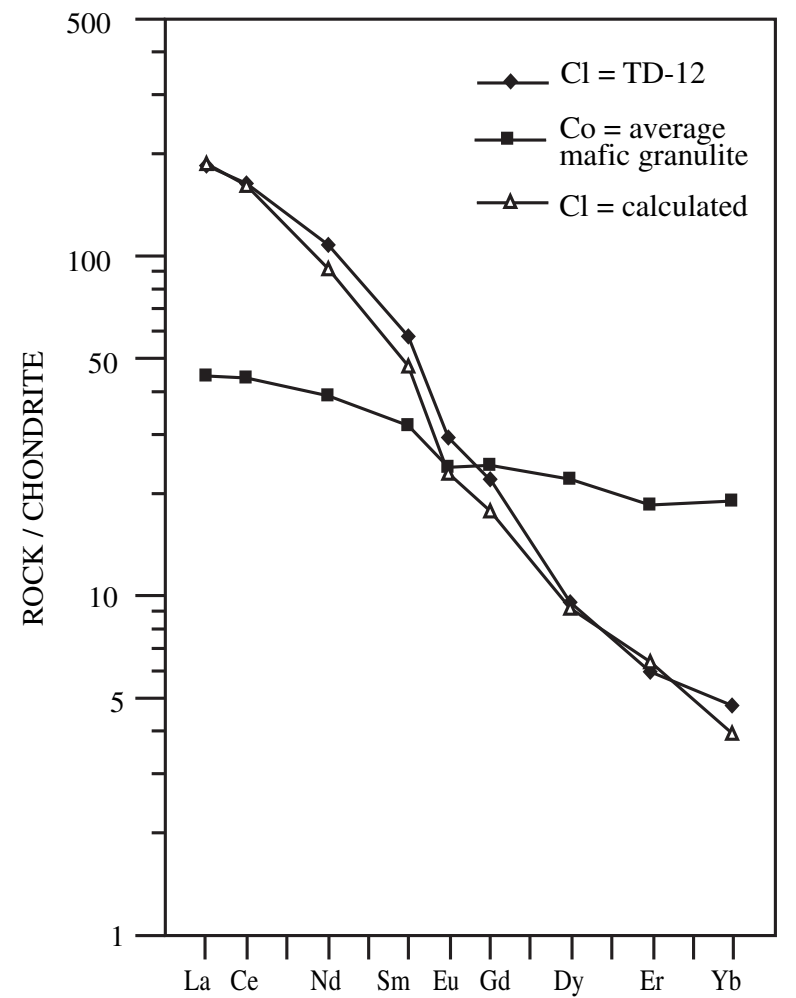

Fig. 10. Chondrite normalized (Masuda et al., 1973) REE pattern showing the result of the modelling of partial melting of average mafic granulite in order to generate TD-12. 


\section{Discussion and conclusions}

Preserved primary minerals are uncommon in the tonalitic and trondhjemitic granulites of the Itabuna-Salvador-Curaçá Block, since they were obliterated by deformation and high-grade metamorphism have obliterated them. Nevertheless the size and textures of some plagioclase, quartz and pyroxene crystals indicate that they belonged to the original plutonic paragenesis that re-equilibrated during granulitic metamorphism. In contrast, the mafic granulites were totally recrystallized during metamorphism. Biotite and hornblende mostly form rims around pyroxenes or are in contact with these minerals, and are considered as secondary or retrograde minerals formed during destabilization of both orthopyroxene and clinopyroxene.

Whole rock geochemistry indicates that the Paleoproterozoic tonalitic and trondhjemitic granulites have low-K calc-alkaline affinities. Oxides such as $\mathrm{TiO}_{2}, \mathrm{Al}_{2} \mathrm{O}_{3}, \mathrm{FeO}, \mathrm{MgO}, \mathrm{CaO}, \mathrm{P}_{2} \mathrm{O}_{5}$ and trace elements such as $\mathrm{V}, \mathrm{Y}$ and $\mathrm{Zr}$ show compatible behaviour, while $\mathrm{Na}_{2} \mathrm{O}, \mathrm{K}_{2} \mathrm{O}$ and $\mathrm{Sr}$ behave incompatibly during magmatic differentiation. These granulites have strongly fractionated REE patterns. The garnet-bearing mafic granulites have tholeiitic affinity, and their REE patterns are almost flat or slightly LREE-enriched with insignificant or no Eu anomalies.

In geochemical modelling the solid extract is mainly made up of plagioclase + hornblende + biotite with subordinate amounts of magnetite, apatite, allanite and zircon. The degree of crystallization is moderate $(\leq 52 \%)$. Many extracts were tested, and all those containing clinopyroxene totally failed to account for differentiated liquid composition. When small amounts $(<5 \%)$ of orthopyroxene are included in the extract, acceptable results are obtained. The adjustment of the calculations to analytical data, however, is far better in the absence of pyroxenes. Therefore, it is concluded that pyroxene fractionation never played a significant role in the genesis of the tonalitic and trondhjemitic magmas. This leads to the conclusion that the magma did not crystallize under granulitic metamorphic conditions but rather under amphibolite facies metamorphic conditions.

The best model accounting for the composition of the tonalitic and trondhjemitic magmas consists in the melting of a metamorphosed basalt source having the same chemical composition as the garnet-bearing basic granulites. The residue of melting being made up of an assemblage of plagioclase, clinopyroxene, garnet, orthopyroxene and hornblende.

\section{Acknowledgements}

Thanks are due to CAPES for the graduate Scholarship awarded to I. C. A. Pinho; to the CNPq for financial support, and to CBPM for logistic support. The collaboration of the graduation Course in Geology and to the Geophysics and Geology Research Centre of the UFBA is gratefully acknowledged. We thank Ian McReath for his help with the English version, and his comments. The authors are also grateful to both reviewers and the regional editor Professor Reinhardt Fuck that greatly added to this work by providing very helpful comments and suggestions.

\section{References}

Alibert, C., and Barbosa J.S.F., 1992. Ages U-Pb determines la SHRIMP sur des zircons du Complexe de Jequié, cráton de São Francisco, Bahia, Brésil. In: Reunion des Sciences de la Terre. Toulouse, Anais. 14 pp.

Alkmim, F.F., Brito Neves, B.B., Castro Alves, J.A., 1993. Arcabouço tectônico do cráton do São Francisco: uma revisão. In: Dominguez, J.M.L., Misi, A. (Eds.), O Cráton Do São Francisco. SBG, SGM, CNPq, Salvador, pp. 45-62.

Alves da Silva, F.C., 1994. Étude Structural du Greenstone Belt Paleoproterozoique du Rio Itapicuru (Bahia, Bresil). PhD Thesis. Université d'Orleans, Orleans, France, 307 p.

Barbosa, J.S.F., 1986. Constitution lithologique et metamorphique de la region granulitique du sud de Bahia-Brésil. PhD thesis. Université Pierre et Marie Curie, Paris, France, 401 p.
Barbosa, J.S.F., 1990. The granulites of the Jequié complex and Atlantic Coast Mobile belt, southern Bahia, Brazil: an expression of Archaen early Proterozoic plate convergence. In: Vielzeuf, D., Vidal, P. (Eds.), Granulites and Crustal Evolution, s. 1. Kluwer Academic, pp. 195-221. il.

Barbosa, J.S.F., Sabaté, P., 2002. Geological features and the Paleoproterozoic collision of four Archaen crustal segments of the São Francisco cráton, Bahia, Brazil: a synthesis. Anais da Academia Brasileira de Ciências 74 (2), 343-359.

Barbosa, J.S.F., Sabaté, P., 2004. Archaen and Paleoproterozoic crust of the São Francisco Bahia, Brazil: geodynamic features. Precambrian Res. 133, 1-27.

Barbosa, J.S.F., Martin, H., Peucat, J.J., 2004. Paleoproterozoic dome forming structures related to granulite facies metamorphism. Jequié block, Bahia, Brazil. Precambrian Res. 135, 105-131.

Bastos Leal, R.L., Cunha, J.C., Cordani, U.G., Texeira, W., Nutman, A.P., Leal, A.B.M., Macambira, J.B.M., 2003. SHRIMP U-Pb ${ }^{207} \mathrm{~Pb} /{ }^{206} \mathrm{~Pb}$ zircon dating and Nd isotopic signature of the Umburunas greenstone belts, northern São Francisco cráton, Brazil: evidence for intraplate extensional tectonics between 33403150 Ma. J. South Am. Earth Sci. 15, 775-785.

Cunha, J.C., Fróes, R.J.B., 1994. Komatiitos com textura "spinifex" do Greenstone Belt de Umburanas, Bahia. Série Arquivos Abertos, 7. CBPM, Salvador, 29 p.

De Souza, Z.S., et al., 2007. Calc-alkaline magmatism at the Archean - Proterozoic transition: the Caicó complex basement (NE Brazil). J. Petrol. 48 (11), 2149-2185.

Foley, S.F., Barth, M.G., Jenner, G.A., 2000. Rutile/melt partition coefficients for trace elements and an assessment of the influence of rutile on the trace element characteristics of subduction zone magmas. Geochimica et Cosmochimica Acta 64, 933-938.

Harker A., 1909. The natural history of the igneous rocks. New York, 384 pp.

Irvine, T.N., Baragar, W.R.A., 1971. A guide to the chemical classification of the common volcanic rocks. Can. J. Earth Sci. 8, 523-548.

Ledru, P., Johan, V., Milési, J.P., Tegyey, M., 1994. Markers of the last stages of the Paleoproterozoic collision: evidence for a 2 Ga continent involving circum-South Atlantic provinces. Precambrian Res. 69, 169-191.

Ledru, P., Milési, J.P., Johan, V., Sabaté, P., Maluski, H., 1997. Foreland basins and goldbearing conglomerates: a new model for the Jacobina Basin (São Francisco Province, Brazil). Precambrian Res. 86, 155-176.

Lobach-Zhuchenko, S.B., et al., 2008. Petrology of a late Archaen, highly potassic, sanukitoid Pluton from the Baltic Shield: insights into late Archean mantle metasomatism. J. Petrol. 49 (3), 393-420.

Marinho, M.M., 1991. La sequence volcano-sédimentaire de Contendas Mirante et la bordure occidental du Bloc de Jequié (cráton du São Francisco, Brésil): un exemple de transition Archéen - Proterozoique. PhD thesis. Universidade de Clermond Ferrand, France, 170 p.

Martin, H., 1986. Effect of steeper Archean geothermal gradient on geochemistry of subduction-zone magmas. Geology 14, 753-756.

Martin, H., 1987. Petrogenesis of archaen trondhjemites, tonalites, and granodiorites from eastern Finland: major and trace element geochemistry. J. Petrol. 28, 921-953.

Martin, H., 1994. The Archean grey gneisses and the genesis of continental crust. In: Condie, K.C. (Ed.), The Archean Crustal Evolution. Elsevier, pp. 205-259.

Martin, H., 1999. Adakitic magmas: modern analogues of Archaen granitoids. Lithos 46 (3), 411-429.

Martin, H., Sabaté, P., Peucat, J.J., Cunha, J.C., 1991. Un Segment de Croute Continentale d'Áge Archéean Ancien (3.4 milliards d'années): le Massif de Sete Voltas (Bahia-Brésil). C.R. Acad. Sci. Paris 313 (Serie II), 531-538.

Martin, H., Moyen, J.-F., 2002. Secular changes in tonalite-trondhjemite-granodiorite composition as markers of the progressive cooling of earth. Geology 30 (4), 319-322.

Martin, H., Smithies, R.H., Rapp, R., Moyen, J.-F., Champion, D., 2005. An overview of adakite, tonalite-trondhjemite-granodiorite (TTG), and sanukitoid: relationships and some implications for crustal evolution. Lithos 79, 1-24.

Mascarenhas, J.F., Silva, E.F.A., 1994. Greenstone Belt de Mundo Novo: caracterização e implicações metalogenéticas e geotectônicas no Cráton do São Francisco: Série Arquivos Abertos, n. 5. CBPM, Salvador, 32 p.

Masuda, A., Nakamura, N., Tanaka, T.,1973. Fine structures of mutally normalized rareearth patterns of chondrites. Geochimica et Cosmochimica Acta 37, 239-244.

Melo, E.F., Xavier, R.P., Mcnaughton, N.J., Fletcher, I., Hagemann, S., Lacerda, C.M.M., Oliveira, E.P., 2000. Age constraints of felsic intrusions, metamorphism, deformation and gold mineralization in the Paleoproterozoic Rio Itapicuru greenstone belt, NE Bahia State, Brazil. In: International Geological Congress, 31, Abstracts. V. Special Symposium. Stable and Radiogenic Isotopes in Metallogenesis. (CD-ROM).

O'Connor, J.T., 1965. A classification for quartz-rich igneous rocks based on feldspar rations. U.S. Geological Survey Professional Papers 525, series B, 79-84.

Oliveira, E.P., Lafon, J.M., Souza, Z.S., 1999. Archaen-Proterozoic Transition in the Uauá Block, NE São Francisco Craton, Brazil: U-Pb, Pb-Pb and Nd isotope constraints. In: SBG, SNET, 7., 1999, Lençóis. Anais. Lençóis 1, pp. 38-40.

Oliveira, E.P., Souza, Z.S., Corrêa Gomes, L.C.C., 2000. U-Pb dating of deformed mafic dyke and host gneiss: implications for understanding reworking processes on the western margin of the Archean Uauá Block, NE São Francisco Craton, Brazil. Rev. Bras. Geoc. 30, 149-152.

Peucat J.J., Santos Pinto M., Martin H., Barbosa J.S., Fanning M.C., 2003. SHRIMP U-Pb zircon ages up to 3.4-3.5 Ga in Archean and Paleoproterozoic granitoids of the Gaviao block, São Francisco Craton, Bahia, Brazil. Short Papers, IV South American Symposium on Isotope Geology, 252-255. 
Pinho, I.C.A., 2000. Os Tonalitos/Trondhjemitos das regiões de Ipiaú-Ubaitaba-Ibicaraí-Itabuna, Bahia. Master. Instituto de Geociências, Universidade Federal da Bahia, Salvador, Brasil, 193 p.

Pinho, I.C.A., 2005. Geologia dos Metatonalitos/Metatrondhjemitos e Granulitos Básicos das Regiões de Camamu-Ubaitaba-Itabuna, Bahia. PhD thesis. Instituto de Geociências, Universidade Federal da Bahia. Salvador. Brasil, 163 p.

Rapp, R.P., Shimizu, N., Norman, M.D., Applegate, G.S., 1999. Reaction between slabderived melts and peridotite in the mantle wedge: experimental constraints at 3.8 GPa. Chem. Geol. 160, 335-356.

Rayleigh, J., 1896. Theoretical considerations respecting the separation of gases by diffusion and similar processes. Philos. Mag. 42, 77-107.

Richard, L.R., 1995. Mineralogical and petrological data processing system (MINPET).

Rios, D.C., Conceição, H., Davis, D.W., Rosa, M.L.S., Marinho, M.M., 2005. Expansão do Magmatismo Granítico Pós-Orogênico no Núcleo Serrinha (Ne Bahia), cráton do São Francisco: Idade U-Pb do Maciço Granítico Pedra Vermelha. Rev. Bras. Geoc. 35 (3), 423-426.

Rollinson, H., 1993. Using Geochemical Data: Evaluation, Presentation, Interpretation. Longman Scientific and Technical, London, 352 pp.

Santos Pinto, M.A., 1996. Le recyclage de la croûte continentale archéene: exemple du bloc du Gavião-Bahia, Brésil. Mémoires de Géosciences Rennes 75, 193.

Smithies, R.H., Champion, D.C., 1999. High-mg Diorite from the Archaen Pilbara Craton: Anorogenic Magmas Derived from a Subduction-modified Mantle. Annual Review 1998-1999. Geological Survey of Western Australia. 45-59.

Shaw, D.M., 1970. Trace element fractionation during anatexis. Geochimica et Cosmochimica Acta 34, 237-243.

Silva, M.G., 1996. Seqüências Metassedimentares, vulcanossedimentares e Greenstone Belts do Arqueno e Proterozóico Inferior. In: Barbosa, J.S.F. Dominguez, J.M.L. (Eds.), Geologia da Bahia: texto explicativo para o mapa geológico ao milionésimo. SICM/SGM, Salvador, pp. 85-102.
Silva, L.C., Armstrong, R., Delgado, I.M., Pimentel, M., Arcanjo, J.B., Melo, R.C., Teixeira, L.R., Jost, H., Cardoso Filho, J.M., Pereira, L.H.M., 2002. Reavaliação da evolução geológica em terrenos Pré-cambrianos brasileiros com base em novos dados U-Pb SHRIMP, parte I: Limite centro-oriental do Cráton do São Francisco. Rev. Bras. Geoc. 32 (4), 501-502.

Stern, R., 1989. Petrogenesis of the Archaen Sanukitoid Suite. State University at Stony Brook, New York, 275 pp.

Stern, R.A., Hanson, G.N., 1991. Archean high-Mg granodiorite: a derivative of light rare earth enriched monzodiorite of mantle origin. J. Petrol. 32, 201-238.

Streckeisen, A., 1976. To each plutonic rock its proper name. Earth Sci. Rev. 12 (1), 1-33. Amsterdam.

Stormer, J.C., Nicholls, J., 1978. XLFRAC: a program for the interactive testing of magmatic differentiation models. Computer Geosci. 87, 51-64.

Sun, S.S., 1980. Lead isotopic study of young volcanic rocks from mid-oceanic ridges, ocean island and island arcs. Phil. Trans. R. Soc. A297, 409-445.

Takahashi, E. 1986. Melting of a dry peridotite KLB-1 up to $14 \mathrm{Gpa}$ implications on the origin of peridotitic upper mantle. In: Taylor, S.R., McLennan, S.M. (Eds.), The Continental Crust: Its Composition and Evolution. J. Geophys. Res., 91, pp. 9367-9382, Blackweel Scientific, Oxford, 312 pp. (1985).

Taylor, S.R., McLennan, S.M., 1985. The contiental Crust: Its Composition and Evolution. Blackweel Scientific, Oxford, $312 \mathrm{pp}$

Teixeira, L.R., 1997. O Complexo Caraíba e a Suíte São José do Jacuípe no Cinturão Salvador-Curacá (Bahia, Brasil): petrologia, geoquímica e potencial metalogenético. PhD thesis. Instituto de Geociências, Universidade Federal da Bahia, Salvador Brasil, 243 p.

Thompson, R.N., 1982. British tertiary volcanic province. Scott. J. Geol. 18, 49-107.

Wilson, N., 1987. Combined $\mathrm{Sm}-\mathrm{Nd}, \mathrm{Pb} / \mathrm{Pb}$ and $\mathrm{Rb}-\mathrm{Sr}$ geochronology and isotope geochemistry in polymetamorphic Precambrian terrains: examples from Bahia, Brazil and Channel Island, U.K. Master. Oxford University, England, 150 p.

Zamora, D, 2000. Fusion de la croûte océanique subductée: approche expérimentale et géochimique. 314 f.Tese, Université Blaise Pascal, Clermont-Ferrand. 